\title{
Venta Belgarum: What Is in the Name for Roman Winchester?
}

\author{
Anthony C. King
}

The name for Roman Winchester, Venta Belgarum, has been known for centuries, and the attribution of the name to modern Winchester has not been in question in any significant way. The purpose of this brief chapter about Barbara Yorke's home town is to look at the two elements of the name, to reflect on recent scholarship, and to make a proposal concerning the second, 'tribal' component.

An essential starting point is the entry for Venta Belgarum in A.L.F. Rivet and Colin Smith's Place-Names of Roman Britain, ${ }^{1}$ in which the name is given as Venta (Ouenta in Greek transliteration) by Ptolemy, ${ }^{2}$ Venta Belgarum or Velgarum in the Antonine Itinerary, ${ }^{3}$ Venta Velgarom in the Ravenna Cosmography, ${ }^{4}$ and also as Venta by Bede. ${ }^{5}$ The last in this list links Venta to Wintancaestir and provides the strongest early medieval evidence for continuity of the first element of the Roman name into the modern toponym. ${ }^{6}$ In addition, the Notitia Dignitatum lists a 'Procurator gynaecii in Britannis Ventensis (var. bentensis)'. This Venta is Winchester, in all probability, but two others, Venta Icenorum (Caister St Edmund, Norfolk) and Venta Silurum (Caerwent, South Wales), are

1 A.L.F. Rivet and Colin Smith, The Place-Names of Roman Britain (London, 1979), p. 492.

2 Ptolemy, Geography, II.3.13, ed. C. Müller (Paris 1883-1901). See also G.R. Isaac, Place-Names in Ptolemy's Geography (Aberystwyth, 2004), CD-ROM s.v. Britt. Inss., Ouenta.

3 Antonine Itinerary, 478.2; 483.2; 486.11, ed. O. Cuntz (Leipzig, 1929). See also G.R. Isaac, The Antonine Itinerary. Land Routes. Place-Names of Ancient Europe and Asia Minor (Aberystwyth, 2002/2004), CD-ROM s.v. Britannia, s.v. Venta; A.L.F. Rivet, "The British Section of the Antonine Itinerary," Britannia 1 (1970), 34-82.

4 Ravennatis Anonymi Cosmographia, 106.18, ed. Joseph Schnetz (Leipzig, 1940), also I.A. Richmond and O.G.S. Crawford, "The British Section of the Ravenna Cosmography," Archaeologia 93 (1949), 1-50.

5 Bede, $H E$, III.7; IV.5; v.23.

6 See Martin Biddle and Birthe Kjølbye-Biddle, "Winchester: from Venta to Wintanccestir," in Pagans and Christians - from Antiquity to the Middle Ages. Papers in Honour of Martin Henig, Presented on the Occasion of his 65 th Birthday, ed. Lauren Gilmour, BAR International Ser. 1610 (Oxford, 2007), pp. 189-214, at p. 207.

7 Notitia Dignitatum, xı.6o, ed. O. Seeck (Berlin, 1876). 
also in contention. ${ }^{8}$ No other direct evidence of the name is known, save the 3rd-century milestones with the formula RPBP, as found in excavations at South Wonston in the 1980s, and in the early 19th century at Bitterne. These have been interpreted as res publica Belgarum posuit ("the council of the Belgae put this up"). ${ }^{9}$

The double-name formula for Roman Winchester is widespread in Britain, Gaul and elsewhere in the Roman Empire. For the most part, the first element is descriptive of the location, while the second has an ethnic component. They are most commonly applied to the so-called civitas capitals, which is a modern term for the administrative centres of civitates (which is a known ancient term for the administrative regions)..$^{10}$ The civitas was thus the territorial unit, with its 'capital' positioned usually but not always centrally within it. In legal terms, the civitas capitals were of lowly status in Roman city hierarchy, and there was the incentive for cities to bid for elevation to municipium (e.g. St Albans) or colonia (e.g. Autun, Avenches).

Such elevation did not happen in the case of Winchester, nor to its neighbours, Silchester (Calleva Atrebatum), Chichester (Noviomagus Regnorum [or Reginorum]) or Dorchester (Durnovaria [Durotrigum]). Two more distant urban centres connected to Winchester on the road system, Cirencester (Corinium Dobunnorum) and London (Londinium), did, however achieve higher status by virtue of being provincial capitals; almost definitely in the case of the latter, less certainly so for Cirencester, which became a capital of Britannia Prima in the late Roman period. ${ }^{11}$ As Rivet suggests, on the basis of Pliny's discussion of Gallic towns and peoples, ${ }^{12}$ it is likely that Winchester was a civitas stipendiaria, a tax-paying town.

Winchester, Silchester and Chichester are relatively close to each other, when compared with the usual distances between towns in Roman Britain. This implies that their civitates were not overly extensive, and when the

$8 \quad$ J.P. Wild, "The Gynaecium at Venta and its context," Latomus 26 (1967), 648-76; W.H. Manning, "Caistor-by-Norwich and Notitia Dignitatum," Antiquity 40 (1966), 6o-62.

9 They were probably set up during the reign of Gordian III. South Wonston: The Roman Inscriptions of Britain, Volume III. Inscriptions on stone found or notified between 1 January 1955 and 31 December 2006, ed. R.S.O. Tomlin, R.P. Wright and M.W.C. Hassall (Oxford 2009), no. 3516. Bitterne: The Roman Inscriptions of Britain, volume 1. Inscriptions on Stone, ed. R.G. Collingwood and R.P. Wright (Oxford, 1965), no. 2222.

10 See generally J.S. Wacher, ed., The Civitas Capitals of Roman Britain (Leicester, 1966); J.C. Mann, "City-names in the Western Empire," Latomus 22 (1963), 777-82.

11 Roger White, Britannia Prima (Stroud, 2007), pp. 36-37.

12 Pliny the Elder, Naturalis Historia, 4.106-109, ed. K.F. Mayhoff (Leipzig, 1875-19o6). A.L.F. Rivet, "Summing-up: Some Historical Aspects of the Civitates of Roman Britain," in Civitas Capitals, ed. Wacher, pp. 101-13, at p. 111, n. 11. 
pre-Roman and early Roman political situation is examined, it becomes clearer as to why this might have been the case.

Our understanding of the Late Iron Age leads most modern commentators to the conclusion that the Atrebates were dominant in the region, up until a short number of years before the Roman conquest of $\mathrm{AD} 43 .{ }^{13}$ This is dependent on the historical narrative built up around Commius and his successors, and also coin distributions. ${ }^{14}$ Whether Commius came to Britain in the late $50 \mathrm{~s}$ BC because he fled from Gaul, ${ }^{15}$ or was sent there by the Romans, ${ }^{16}$ is not a point of contention here. The coin distributions are of more importance, and appear to indicate an area encompassing Silchester, Winchester, Chichester, together with parts of Surrey and coastal Sussex..$^{17}$ Interestingly, Winchester lies on the western margin of this area, which conceivably had the River Itchen as a boundary; Dobunnic land lay to the west and north-west, Durotrigan territory to the south-west, and an area defined as possibly sub-Durotrigan was to the south, ${ }^{18}$ in the New Forest and Southampton Basin. This may have a bearing on the civitas territory of Roman Winchester, discussed further below.

Coins of Commius are found in the same general area as uninscribed coins attributed to the Atrebates or their predecessors, ${ }^{19}$ and there are also postCaesarian coins of Commius in Atrebatan territory in Gallia Belgica. ${ }^{20}$ This gives us a picture of a region, perhaps called the land of the Atrebates, under some sort of dynastic control, often termed the Southern Dynasty. This was the position during the 1st century вС and in the first two decades of the 1st century AD. After this, the politico-military situation changed, with the loss of Silchester and much of the territory, whether through military or dynastic succession being difficult to tell. ${ }^{21}$ Coins of Epaticcus, of the so-called Eastern

13 Barry Cunliffe, "Iron Age Wessex: Continuity and Change," in Aspects of the Iron Age in Central Southern Britain, ed. Barry Cunliffe and David Miles (Oxford, 1984), pp. 12-45, esp. p. 37, Fig. 2.19; Barry Cunliffe, Iron Age Communities in Britain, 3rd ed. (London, 1991), pp. 149-57; Barry Cunliffe, Wessex to A.D. 1000 (Harlow, 1993), pp. 208-13; Lyn Sellwood, "Tribal Boundaries Viewed from the Perspective of Numismatic Evidence," in Aspects of the Iron Age, ed. Cunliffe and Miles, pp. 191-204, esp. p. 192, figs 13.1, 13.8, 13.11; John Creighton, Coins and Power in Late Iron Age Britain (Cambridge, 2000), Ch. 3 .

14 Creighton, Coins and Power, pp. 59-79.

15 Frontinus, Strategemata, 2.13.11, ed. C.E. Bennett (Harvard, 1925).

16 Caesar (Hirtius), De Bello Gallico, 8.48, ed. Anne Wiseman and Peter Wiseman (London, 1980). Creighton, Coins and Power, pp. 61-64.

17 Creighton, Coins and Power, p. 223.

18 Sellwood, “Tribal Boundaries," Fig. 13.11.

19 Simon C. Bean, The Coinage of the Atrebates and Regni (Oxford, 2000), pp. 119-20.

20 Creighton, Coins and Power, pp. 72-74.

21 John Creighton, Britannia. The creation of a Roman Province (London, 2006), p. 27. 
Dynasty, are found in much of the region, ${ }^{22}$ and may represent changed realities of power in the 30 s and $40 \mathrm{AD}$. This, in turn, led to Verica's famous appeal to Rome and the Claudian invasion.

Winchester does not figure in this narrative, nor do the Belgae. The archaeological evidence from the town suggests that the Middle Iron Age enclosure at Oram's Arbour continued to be Winchester's focus in the Late Iron Age, but the intensity of occupation was less than in earlier times, and extensive evidence for houses and domestic occupation is not really forthcoming. ${ }^{23}$ There are some material traces, including 'coin-moulds', but it is possible that the enclosure was more of an open space, used for trading and exchange. It had a demonstrably strategic location, on an east-west routeway where it crossed the north-south waterway of the R. Itchen at a convenient, probably fordable, point. It also may have been on a boundary location between the Atrebates and peoples further to the west. Oram's Arbour was probably the Venta of Winchester's Roman name, and it is to the etymology of this word that we now turn.

Venta is an intriguing word, and has seen a variety of translations. As discussed by Rivet and Smith, it is "a well-known problem," and they conclude that "the three civitas-names with Venta are a puzzling feature considered as an isolated and untypical naming act." 24 Their preferred translation is "marketplace," a British Celtic (Brittonic) word, possibly also seen in Late Latin vendita, 'market'. As such, this would fit Oram's Arbour well, in its Late Iron Age guise, and it may be, as Rivet and Smith suggest, that Venta Belgarum, Venta Icenorum and Venta Silurum are a uniquely British equivalent of the more widespread Roman naming practice of Forum plus name of a people or territory, as in Forum Segusiavorum (Feurs, France) and several other examples. ${ }^{25}$ Graham Isaac also gives the meaning of Venta as "market-place; administrative centre," presumably on the same basis. ${ }^{26}$

22 Creighton, Coins and Power, p. 77.

23 K.E. Qualman, et al., Oram's Arbour. The Iron Age Enclosure at Winchester. Volume 1: Investigations 1950-1999 (Winchester, 2004), p. 90.

24 Rivet and Smith, Place-Names, pp. 262-65. See also Richard Coates, "Remarks on 'preEnglish' in England: with Special Reference to "ventā, "ciltā and *cunāco," JEPNS 16 (1984), 1-24, esp. pp. 1-7; T.S.Ó Máille, “Venta, Gwenta, Finn, Guen," Nomina 11 (1987), 145-51; John T. Koch, "Bannaventa, Borough Hill (Northamptonshire), and Welsh mynwent," Studia Celtica 50 (2016), 169-74.

25 Alexander Falileyev, Dictionary of Continental Celtic Place-Names. A Celtic companion to the Barrington Atlas of the Greek and Roman World (Aberystwyth, 2010), p. 125.

26 Isaac, Antonine Itinerary, CD-ROM, s.v. Celtic elements etymology, s.v. uenta. See also Patrick Sims-Williams, Ancient Celtic Place-Names in Europe and Asia Minor (Oxford, 2006), p. 118; Fernando Fernández Palacios, "The Theonym *Conventina," in Celtic Religions in the 
But the meaning of Venta needs further discussion. Kenneth Jackson pointed out many years ago that the word does not have a convincing Celtic etymology, and it does not survive in any derived forms in regional Celtic languages such as Cornish or Breton. ${ }^{27}$ However, Ifor Williams equated the word with the Welsh suffix -went, as in Cadwent or Llinwent. ${ }^{28}$ The meaning in these cases would be 'field', and thus 'battlefield' and 'flax-field' respectively. It is this usage that probably fits best with -venta when used as a suffix in the two Roman place-names in Britain, Bannaventa (Whilton Lodge, Northants) and Glannoventa (Ravenglass, Cumbria); the former is "field on the prominence" or "market on the promontory," and the latter "shore field" or "market on the shore."29 In other words, this meaning implies an open-air market, or a gathering place or field, which again would fit Oram's Arbour well.

Recent discussion of venta as a word or word element has focussed on other possibilities. Delamarre derives the word from Gallo-Brittonic *wenta, and Indo-European * $g^{w h} e n-t a$, with the meaning 'place of slaughtering of animals' or 'place of sacrifice of animals'. ${ }^{30}$ This, too, would fit with the notion of Oram's Arbour being where animals were killed for the market, or possibly at religious ceremonies. All three of the British Venta towns could be associated with this type of activity, especially in respect of the marketing, slaughter and perhaps sacrifice of sheep and cattle. ${ }^{31}$

Roman Period. Personal, Local, and Global, ed. Ralph Haeussler and Anthony King (Aberystwyth, 2017), pp. 165-75, esp. n. 40.

27 Kenneth Jackson, "Romano-British names in the Antonine Itinerary," in Rivet, "British Section of the Antonine Itinerary," p. 80.

28 Ifor Williams, notes on etymology, in Richmond and Crawford, "British Section of the Ravenna Cosmography," pp. 27, 48.

29 Rivet and Smith, Place-Names, pp. 262-64, 367, 511-12. Koch, Bannaventa, pp. 171-72, interprets Bannaventa as 'the place rich in peaks', and Glannoventa as 'the place of river banks, shores', thus giving the *-uent- element a simpler locational character.

$30 \quad$ Xavier Delamarre, "Notes d'onomastique vieille-celtique," Keltische Forschungen 5 (201012), 99-137, esp. pp. 126-29; Xavier Delamarre, Noms de lieux celtiques de l'Europe ancienne (Paris, 2012), p. 27. There is a root, -uen, underlying the word venta. Van Hamel long ago related this to the Celtic *gwent 'worry, excitement', but Delamarre's derivation from Indo-European is now preferred. Cf. A.G. Van Hamel, "La racine uen- en celtique et en germanique," in Mélanges linguistiques offerts à M. Holger Pedersen à l'occasion de son soixante-dixième anniversaire (Copenhagen, 1937), pp. 103-09. I am grateful to Fernando Fernández for drawing my attention to these references.

31 Cf. Anthony King, "Regional Factors in the Production and Consumption of Cattle, Sheep and Goats, and Pigs in Roman Britain," in The Role of Zooarchaeology in the Study of the Western Roman Empire, ed. Martyn G. Allen and Mark Blagg-Newsome (Portsmouth, RI, 2019), p. 41, for discussion of animal husbandry, especially Late Iron Age emphasis on sheep husbandry on the Wessex downland. 
The possible ritualistic association for Venta, as proposed by Delamarre above, leads us to a similar linkage, in the form of the goddess name Coventina or *Conventina. She is found at a single site, the shrine and well to the nymph of that name, adjacent to Carrawburgh fort on Hadrian's Wall. ${ }^{32}$ The name is probably composed of con-, -vent- and the adjectival -ina. Thus, venta is encapsulated in this theonym, and has been the subject of wide-ranging discussion as a consequence. ${ }^{33}$ Fernandez explored the possibility that the vent or uent component might have an Indo-European non-Celtic root related to water, and, as aired by Olmstead, ${ }^{34}$ it could be a nasalised form of Indo-European "ued- 'wet', from which we have Germanic *uent-, English winter 'wet season'. There is also Indo-European *auent- 'to wet; a spring', from which river names can be derived, e.g. R. Ant, Norfolk. ${ }^{35}$ We can even invoke here the hydronym Solent, attested as Soluente in the early 8th century $\mathrm{AD},{ }^{36}$ which may include the element uent in its watery interpretation. As far as Winchester is concerned, the watery meaning of the word seems less applicable than a field/ market interpretation, unless the close proximity of the R. Itchen, and marshy ground to north and south of the city, may have a bearing on the meaning of the word. ${ }^{37}$

32 Lindsay Allason-Jones and Bruce McKay, Coventina's Well. A Shrine on Hadrian's Wall (Chesters, 1985).

33 Fernández, "*Conventina"; Patrizia De Bernardo Stempel, "Continuity, translatio and identificatio in Gallo-Roman Religion: the Case of Britain," in Continuity and Innovation in Religion in the Roman West, 2, ed. Ralph Haeussler and Anthony King (Portsmouth, RI, 2008), pp. 67-82. I am also grateful to participants in the discussion of Venta and Coventina at the Fontes epigraphici religionum celticarum antiquarum (FERCAN) conference at Lampeter, 2014, following Fernando Fernández's paper. For Spanish analogous deity names, see Elizabeth Richert, Native Religion under Roman Domination: deities, springs and mountains in the north-west of the Iberian Peninsula (Oxford, 2005), no. 81, Cohventena, no. 82, Cuhue(tena?).

34 Garrett S. Olmstead, The Gods of the Celts and the Indo-Europeans (Budapest, 1994), pp. 427-28.

35 Fernández, "“* Conventina." See also Aventicum (Avenches, Switz.), which may be 'town of the river-dwellers'. The name is thought to be 'indigenous, perhaps Celtic'; Falileyev, Dictionary, p. 103.

36 S. Hilsberg, Place-Names and Settlement History. Aspects of Selected Topographical Elements on the Continent and in England (Leipzig, 2009), p. 48; David Tomalin, "The Solent in Prehistory," in The Book of the Solent, ed. Maldwin Drummond and Robin McInnes (Chale, 2001), pp. 13-32, esp. p. 14; A.D. Mills, A Dictionary of English Place-Names (Oxford, 1991), s.v. Solent.

37 It is pertinent in this respect that both Venta Icenorum and Venta Silurum have analogous geographical positions to that of Winchester, being located adjacent to rivers on ground that was relatively protected from flooding. Cf. Ó Máille "Venta," pp. 146-47, for further discussion. 
Although most interpretations of venta give a Celtic or Gallo-Brittonic origin, Jackson was clear in stating that the word had difficulties in Celtic etymology, and as seen above, Fernandez actively explored the possibility of an IndoEuropean non-Celtic derivation..$^{38}$ In the case of Coventina, there is a possible Germanic link, which Fernandez felt unqualified to pursue, but has been discussed by Clay in relation to the Germanic dedicants at the shrine. ${ }^{39}$ Coventina's Well was built at the time that the 1st Cohort of Batavians was at Carrawburgh, and there are dedications made by men of the 1st Cohort of Frisians and the 1st Cohort of the Cuberni (Cugerni). Other dedications at Carrawburgh were by the and Cohort of Nervians, and there are several phonetically Germanic personal names, as well as reference to germanus as self-description by dedicants. Clay suggests that "the cult-centre was used to construct and maintain Germanic social networks." 40

What relevance does this Germanic link have to Venta Belgarum? To approach the answer to this, we need to return to Commius and the second, Belgic, element of Winchester's Roman name. The continental coinage of Commius has a pairing with the Garmanos, a word which also appears on coins in combination with other personal names. ${ }^{41}$ These coins are found in the territory of the continental Atrebates (around modern Arras) and in the Aisne valley further south. Garmanos may be a second individual, but equally could be an epithet. If the latter, we may have a variant of Germanos, remembering that conventional Latin pronunciation of both variants would be with a hard ' $\mathrm{g}$ ' and thus closer than modern usage would suggest. It is a moot point whether Garmanos can be identified with Germanus, ${ }^{42}$ but if it can, was Commius

38 Jackson, "Romano-British names," p. 80; Fernández, "*Conventina."

39 Cheryl Clay, "Before there were Angles, Saxons and Jutes: An Epigraphic Study of the Germanic Social, Religious and Linguistic Relations on Hadrian's Wall," in Pagans and Christians (see above, n. 6), pp. 47-63, esp. pp. 52-53. See also Cheryl Clay, "Developing the 'Germani' in Roman Studies," in TRAC 2007. Proceedings of the Seventeenth Annual Theoretical Roman Archaeology Conference, ed. Corisande Fenwick, Meredith Wiggins and David Wythe (Oxford, 2008), pp. 131-50, esp. p. 147.

$40 \quad$ Clay, "Before there were Angles," p. 53.

41 Creighton, Coins and Power, pp. 72-74. See also Richard Coates, "The British Dynasty of Commius: A Philological Discussion," Studia Celtica 45 (2011), 185-92, for discussion of Commius and his lineage.

42 I am grateful to an anonymous reviewer of this paper for the following comment: "The change of $[\mathrm{er}]>[\mathrm{ar}]$ before a consonant is known in Vulgar Latin/Proto-Romance, but its dating is uncertain. The ist century [BC] would be a very early case indeed. The change ... is also well-known later as a feature of British Celtic in the transition to Brittonic. However, a connection of its base with the ancestor of Welsh garm 'shout, outcry, clamour' might also be considered." 
self-styled as 'german' and if so, how does this relate to Gallia Belgica and Venta Belgarum?

It was recognised by Caesar that Gallia Belgica had a different language from much of Gaul (i.e. from the later Roman province of Gallia Lugdunensis), ${ }^{43}$ but one which was assumed to be mutually understandable with Gallic, and consequently, to be of Celtic or Gallo-Brittonic lineage. The word Belgae itself has a Celtic meaning as 'proud ones.' ${ }^{4}$ However, in Gallia Belgica, Celtic placenames are uncommon in parts of the region, especially north of the Ardennes, leading Wightman to suggest that much of the population had a non-Celtic language, even if the aristocracy spoke Celtic or were multi-lingual. ${ }^{45}$ It is likely that the large swathe of land between the Seine, the Moselle and the Rhine, encompassing Gallia Belgica and Germania Inferior, contained a number of languages in the pre-Roman period, some more 'Celtic', others more 'Germanic'. There was probably not a Belgic language as such, but clearly the territory had a distinct identity, enough for Caesar to remark on it, and for it to be named Gallia Belgica.

Commius, therefore, had a Belgic identity, was also called "the Atrebatan" by Caesar, ${ }^{46}$ and may have used the epithet Garmanos (or at least be paired with someone of that name). We know that he had control or influence over the Morini, the Bellovaci and the Nervii as well as the Atrebates, ${ }^{47}$ and was a worthy founder and king (rix or rex) of the Southern Dynasty when he eventually came to Britain.

To anticipate the final conclusion to this paper, if we move forward to urban naming after the Roman conquest, we see the Commian legacy reflected in the second elements of the three cities of the Atrebates. Silchester took the Atrebatan aspect, Chichester the possibly royal (Regini or Regni) aspect ${ }^{48}$ and lastly, Winchester, the Belgic aspect. It was the conscious re-forging of a regional identity over the old Atrebatan Iron Age kingdom, created in the wake of the restoration of the status quo after the successful Roman conquest of the area. We shall probably never know whether pre-Roman Winchester housed Belgic

\footnotetext{
43 Caesar, De Bello Gallico, 1.1.

44 Rivet and Smith, Place-Names, p. 267.

45 Edith Mary Wightman, Gallia Belgica (London, 1985), p. 11. See also Creighton, Coins and Power, Ch. 6, on social hierarchies and language use in the Late Iron Age.

46 Caesar, De Bello Gallico, 4.27.

47 Creighton, Coins and Power, pp. 59-61. Coates, "British dynasty of Commius."

48 The usual interpretation of Regni gives it a 'royal' association, but there is uncertainty surrounding the etymology of this name, and an alternative is ${ }^{*}$ regini 'proud ones, stiff ones'; Rivet and Smith, Place-Names, p. 446.
} 
people from Gallia Belgica, and possibly non-Celtic speakers. ${ }^{49}$ The doubts discussed above concerning the Celtic derivation of Venta are relevant, however, and it may just be the case that the word has some form of non-Celtic, even Belgic cultural linkage, albeit tenuous for the latter, given the lack of evidence for venta elements in Gallia Belgica itself.

A last issue to tackle is the question of when the full double-name formulation of Venta Belgarum was applied to Winchester. The literary authorities are interesting in this respect, as the earliest, Ptolemy, c. AD 140-50, gives only Venta, a polis of the Belgae. ${ }^{50}$ The next, chronologically, is the Antonine Itinerary, which probably does not have a single date, being a compilation of different official routes, but is probably to be placed between the reigns of Trajan and Diocletian. ${ }^{51}$ It gives the double formula Venta Belgarum. On the face of it, therefore, Venta is the primary name, and Belgarum is an add-on which was gaining currency, in official documents at least, during the 2nd century.52

Ptolemy's text implies that the Belgae were a recognisable entity (whether actual people or an administrative unit) by the mid-2nd century, and therefore

49 This is not to take the avowedly non-Celtic line of Michael Goormachtigh and Anthony Durham, "Kentish place-names - were they ever Celtic?" Arch. Cant. 129 (2009), 279-93. See, however, Stephen Yeates, Myth and History. Ethnicity and Politics in the First Millennium British Isles (Oxford, 2012), for discussion of, for him, a strong German element amongst the Belgae. Daphne Nash, "The Language of Inscriptions on Icenian Coinage," in The Iron Age in Northern East Anglia. New Work in the Land of the Iceni, ed. J.A. Davies, BAR Brit. Ser. 549 (Oxford, 2011), pp. 83-102, similarly discusses the German linguistic aspect of the Icenian evidence.

5o Ptolemy, Geography, 2.3.13. The two other places attributed to the Belgae by Ptolemy are Aquae Calidae (Bath) and Ischalis (unlocated). He also states that the Belgae are below (i.e. south of) the Dobunni. Ptolemy is the only source for such a westerly extension of the territory of the Belgae, and this is usually regarded as incorrect, for discussion of which see Rivet and Smith, Place-Names, p. 256. However, Martin Henig, in various publications ("From Classical Greece to Roman Britain: Some Hellenic Themes in Provincial Art and Glyptics," in Periplous. To Sir John Boardman from his Pupils and Friends, ed. G.R. Tsetskhladze, A.J.N.W. Prag and A.M. Snodgrass (London, 1999), pp. 172-85; "A New Star Shining Over Bath," Oxford Journal of Archaeology 18:4 (1999), 419-25; The Heirs of King Verica. Culture and Politics in Roman Britain (Stroud, 2002), p. 48), makes a case for Bath coming under the control and patronage of Togidubnus, after the emperor had granted the king additional territory as a reward for his loyalty to Rome (Tacitus, Agricola, 14, ed. R.M. Ogilvie and Ian Richmond [Oxford, 1967]).

$5^{1} \quad$ Rivet and Smith, Place-Names, p. 153 .

$5^{2}$ It is worth noting the relatively late date for this. A consequence may have been that the first element of the place-name had a much stronger hold on popular usage, and therefore survived in the medieval and modern place-name. This contrasts with the Gallic situation, where late and post-Roman names took on the ethnic element, e.g. Bellovacis (Beauvais), Suessiones (Soissons). 
had a geographical existence prior to this date. As outlined above, we have reasons to believe that Belgic as an epithet associated with the Atrebates was in existence well before the conquest of $\mathrm{AD} 43$. The question at this point is why Belgarum was applied to Winchester as opposed to one of the other two towns in the old Atrebatic region, and when the civitas of this name became a distinct entity.

The notion of the 'friendly king' and client kingship has been the subject of much discussion in relation to Roman Britain, notably concerning Tiberius Claudius Togidubnus and the inscription with his name at Chichester. ${ }^{53}$ Much of the debate is not relevant to this paper, but we need to note John Creighton's argument that the Southern Dynasty was, in effect, a client kingdom prior to AD 43, since Caesar's invasion was nominally at least, a conquest, and in consequence, Commius had been accepted as king of the Atrebates by Rome. In this scenario, Commius was the first in a line of kings that ended with Togidubnus, and on the latter's death, the Roman governor took full control and the client kingdom came to an end.

Creighton also has a maximalist view of the extent of Togidubnus' area of power and influence, with him being entrusted with an area larger than the old Atrebatic kingdom, to encompass a significant part of southern and southeastern Britain, at a time when the Roman governor was actively undertaking military operations further to the north and west. ${ }^{54}$ Russell also maps out a large territory for Togidubnus, taking in central southern Britain, as far west as Bath, and north into the south and east Midlands. ${ }^{55}$ A more circumscribed

53 The Roman Inscriptions, 1 (see above, n. 9), no. 91. The main literature on client kings in Britain, and Togidubnus, is Anthony A. Barrett, "The career of Tiberius Claudius Cogidubnus," Britannia 10 (1979), 227-42; Anthony A. Barrett, "The civitates of Tiberius Claudius Cogidubnus," Echos du Monde Classique/Classical Views 26 (1982), 45-55; David C. Braund, Rome and the Friendly King. The Character of Client Kingship (London, 1984); David C. Braund, Ruling Roman Britain. Kings, queens, governors and emperors from Julius Caesar to Agricola (London, 1996); Creighton, Coins and Power; Creighton, Britannia; Miles Russell, Roman Sussex (Stroud, 2006), Chs. 1-2; Miles Russell, Bloodline. The Celtic Kings of Roman Britain (Stroud, 2010), Ch. 8. It is current practice and philological preference to spell Togidubnus rather than Cogidubnus, but either is potentially correct (Richard Coates, “Cogidubnus Revisited," AntJ 85 (2005), 359-66; see also Russell, Bloodline, p. 109). It is not accepted here, as Russell contends, that Togidubnus and Togodumnus were the same person. However, it is entirely possible that Togidubnus was not related to the Commian dynasty and had been put into power by the Romans after the death of Verica.

54 Creighton, Britannia, p. 31. See also Colin C. Haselgrove, "Romanization before the Conquest: Gaulish Precedents and British Consequences," in Military and Civilian in Roman Britain, ed. T.F.C. Blagg and A.C. King, BAR Brit. Ser. 136 (Oxford, 1984), pp. 1-64, esp. p. 36. See also Henig, Heirs, p. 48.

55 Russell, Bloodline, p. 111, Fig. 57. 
area for the client kingdom is the old Atrebatic kingdom without further territory, and this is accepted by Barrett ${ }^{56}$ and in most of the general textbooks on Roman Britain. There is also a minimalist position, which gives Togidubnus just the territory of Chichester (i.e. the Regnum). ${ }^{57}$ For reasons given earlier in this paper, the old Atrebatic kingdom seems to be the natural unit for the postClaudian area under Togidubnus' control.

Roman Winchester, therefore, was likely to have started post-conquest life as a market and administrative centre within the client kingdom. It was, to some extent, the junior of the three Atrebatic urban centres in terms of its early development. Silchester has extensive evidence for major pre-Roman development, and as an oppidum, was significantly larger than Winchester. ${ }^{58}$ It also had high-status construction soon after the conquest, which Fulford postulates as a possible palace for the client king, with Neronian imperial assistance. ${ }^{59}$ Chichester, too, was an extensive 'territorial' oppidum, with much early development focused on the Fishbourne area, and also the possible building of a contemporary palace there for the client king. ${ }^{60}$ So far, we do not have the equivalent at Winchester, and the oppidum enclosure of Oram's Arbour, while being a respectable $20 \mathrm{ha}$, is not on the same scale as the immediate pre- and post-conquest occupation at Silchester and Chichester.

The Roman town, partially overlying Oram's Arbour, and presumably bringing about the latter's abandonment as an enclosure, has its own earthwork defences, that can be dated to the late Neronian or early Flavian period. ${ }^{61}$ It looks as though the initial development of the Roman town, eventually into one of the larger towns in Britannia, started from these relatively humble beginnings. In some respects, it can be characterised as a deliberate revivification of the earlier market-place or Venta of Oram's Arbour, as a town on the western margin of the old Atrebatic territory. This must have taken place while the client kingdom was still in existence, and it is possible that Togidubnus' sphere of

$56 \quad$ Barrett, "Career"; Barrett, "Civitates."

57 Barry Cunliffe, The Regni (London, 1973), p. 23. Braund, Ruling, p. 111, also appears to lean towards this position.

$5^{8}$ John Creighton and Robert Fry, Silchester: Changing Visions of a Roman Town (London, 2016), Ch. 11 .

59 Michael Fulford, "Nero and Britain: The Palace of the Client King at Calleva and Imperial Policy Towards the Province after Boudicca," Britannia 39 (2008), 1-13; Michael Fulford and Jane Timby, Late Iron Age and Roman Silchester. Excavations on the Site of the ForumBasilica 1977, 1980-86 (London, 2000), pp. 567-68. See also Jillian Greenaway, "The Neronian Stamped Tile from Little London, near Silchester," Britannia 12 (1981), 290-91.

6o Fulford, "Nero," p. 10.

61 See the summary in John Wacher, The Towns of Roman Britain, 2nd ed. (London, 1995), pp. 291-93. 
influence had allowed for expansion to the west, thus extending what was later to become the Belgic civitas into western and south-western Hampshire and probably beyond. ${ }^{62}$

Autonomy for Winchester, as a civitas-capital after the end of the client kingdom, cannot be easily dated, because we do not know when Togidubnus died. Barrett suggests an early date, in the mid-6os AD, and this, or even earlier in the late 50s, was accepted by Braund, and initially, by Fulford. ${ }^{63}$ However, Fulford's re-evaluation of the early building evidence at Silchester has led him to discard a Neronian date and argue for construction taking place on behalf of the client kingdom during the 6os AD, after Boudica's rebellion. ${ }^{64} \mathrm{~A}$ Flavian date for the death of Togidubnus is the current view, while acknowledging that we will never have certainty. ${ }^{65}$ Tacitus records that Togidubnus had remained loyal 'down to our times', which was the late Flavian period or later. ${ }^{66}$ This would make Togidubnus very elderly at the time of his death, and therefore the phrase is often taken as a literary generalisation.

By way of conclusion, we must return to the word Belgae. Caesar stated that "maritime regions" of Britain had been settled before the time of his own invasion, by "invaders who crossed from Belgium (ex Belgio) for the sake of plunder, and then, when the fighting was over, settled there: these people have almost all kept the names of the tribes from which they originated."67 This led Barry Cunliffe to suggest that the area in question included the shores of the Solent and further inland, and that this had taken place c. $100 \mathrm{BC}$, representing the beginnings of the Late Iron Age dispositions in the region. ${ }^{68}$ This could, of course, mean that a group or groups of people in the region styled themselves Belgae (but it must be noted that there are no people of this name 'of the tribes from which they originated', as Caesar put it), and that this was crystallised eventually into the name for Roman Winchester.

As we know, however, from what developed in the period after Caesar's invasion, the region became part of the Atrebatic kingdom under Commius.

62 But probably not as far west as Bath, see n. 47; Wacher, Towns, p. 293. Contra, Fulford, "Nero," p. 11.

63 Barrett, "Career," p. 242; Braund, Ruling, p. 112; Fulford and Timby, Forum-Basilica, p. 569.

64 Fulford, "Nero."

65 See Creighton, Britannia, p. 152; Russell, Roman Sussex, p. 42.

66 Tacitus, Agricola, 14. A very late date for Togidubnus' death is accepted by Henig, Heirs, p. 56. This is based, in part, on the substantial changes to Fishbourne palace at the end of the ist century being put in place after his death, and on the possible patronage by Togidubnus of the development of Bath as a religious centre during the Flavian period. See n. 49 .

67 Caesar, De Bello Gallico, 5.12.

68 Cunliffe, Wessex, pp. 205-06; Britain Begins (Oxford, 2012), p. 334. 
A possible consequence would have been the incorporation of the loosely named Belgae into the political structure of the kingdom, ${ }^{69}$ with Venta Belgarum encapsulating a memory of this in its name. Alternatively, and perhaps preferably, it may have taken Belgarum as a descriptive ethnic epithet, 'proud ones', deriving from the ethnic identity of the Atrebatic kings. When the three towns were established as civitates, probably in the Flavian period, Silchester kept the 'tribal' name, Chichester took the 'regal' name, ${ }^{70}$ and Winchester had its proud reference to the ancestral spirit of the old Atrebatic realm. ${ }^{71}$

69 It is conceivable that the Belgae were a subordinate unit within the Atrebates, as also possibly for the Regini around Chichester.

70 Or alternatively, an epithet derived from *regini 'proud ones, stiff ones'; Rivet and Smith, Place-Names, p. 446. See n. 48.

71 I am very grateful to Dr Martin Henig and a second, anonymous, reviewer for their helpful and useful comments on this paper. 